\title{
TREATMENT OF FRACTURES OF THE FEMORAL NECK BY REPLACEMENT WITH THE THOMPSON PROSTHESIS
}

\author{
John D'Arcy and Michael Devas, Hastings, England
}

\begin{abstract}
The case histories of 361 subcapital fractures of the femoral neck in 354 patients treated by primary replacement with the cemented Thompson prosthesis were reviewed, and 156 survivors were seen at follow-up. The average age was eighty-one years. Three hundred and thirty fractures occurred in women and thirty-one in men. The antero-lateral approach to the hip was used at all operations because it allows immediate and unrestricted mobilisation after operation. It is considered that this method is the best treatment in the rehabilitation of elderly patients after high femoral neck fractures, because of its low morbidity and high success rate in returning the geriatric orthopaedic patient to independence. The results after an average of just over three years were available for 161 hips in 156 patients studied at follow-up. Of these, 132 (82 per cent) were satisfactory. Most of the unsatisfactory results were in patients under seventy-five years of age. Out of the whole group of 361 hips treated the important early complications were wound infections in seventeen hips (4.7 per cent), all of which resolved, and dislocation in seven hips ( 2 per cent). Forty-six patients (12.9 per cent) died during the first four weeks after operation, their average age being eighty-five. One hundred and seventy-one patients $(47 \cdot 4$ per cent) were discharged from hospital within under four weeks of the operation. Acetabular erosion and loosening are shown to be the important later complications. Three patients had late sepsis.
\end{abstract}

During the nineteenth century the advice of Sir Astley Cooper, with regard to high fractures of the femoral neck, was to treat the patient and let the fracture go (Cooper 1822). He recognised that most patients who sustained this injury tolerated prolonged immobilisation poorly. During the past half century technical improvements have made it possible to treat these patients without prolonged bed rest (Smith-Petersen, Cave and Van Gorder 1931; Moore 1952; Thompson 1954; Garden 1961, 1964). It is now recognised that whatever the treatment adopted in the elderly patient it should allow immediate and unrestricted rehabilitation (British Medical Journal 1969; Devas 1974). There is still controversy on whether treatment should be by internal fixation-in the hope of achieving union without avascular necrosis-or by replacement arthroplasty. Eloquent pleas have been made in favour of preserving the femoral head (Dickson 1953; Nicoll 1963; Barnes 1970); and authors aiming to compare the results of internal fixation and replacement arthroplasty have all favoured internal fixation (Boyd and Salvatore 1964; Hunter 1969; Lunt 1971; Raine 1973). But in each series older and less fit patients have been chosen for arthroplasty, and it follows that in such circumstances the results of internal fixation are likely to be better. Good results have been reported by other writers favouring arthroplasty as the treatment of choice for displaced subcapital fractures in the elderly (Addison 1959; Hinchey and Day 1964; Burwell 1967; Riska 1971).

\section{CLINICAL MATERIAL}

The case histories of 354 patients with 361 fractures of the femoral neck treated by Thompson arthroplasty using cement have been reviewed (Table I). Women outnumbered men by over ten to one. The overall average age of the patients was eighty-one years (Fig. 1). The operations were done at the Royal East Sussex Hospital, Hastings, by various surgeons (Table II) between December 1966 and December 1972. The notes of a further eleven patients known to have had the operation could

TABLE I

Clinical Material

\begin{tabular}{|c|c|c|c|}
\hline & & Patients & Hips \\
\hline Total & . & 354 & 361 \\
\hline Women . & . & 323 & 330 \\
\hline Men & . & 31 & 31 \\
\hline Long-term $\mathrm{f}$ & llow-up & 156 & 161 \\
\hline Now dead & . & 174 & 176 \\
\hline Too ill to as & ess & 3 & 3 \\
\hline Not followe & up & 21 & 21 \\
\hline Left side & . & - & 200 \\
\hline Right side & . & - & 161 \\
\hline
\end{tabular}

John C. D'Arcy, F.R.C.S., Orthopaedic Senior Registrar, Guy’s Hospital, London SE1 9RT, England. Michael Devas, M.Chir., F.R.C.S., Consultant Orthopaedic Surgeon, Royal East Sussex Hospital, Hastings, England. 
not be found and had probably been destroyed in a fire. Ten other patients known to be alive were not able to be seen.

\section{MANAGEMENT}

Thompson arthroplasty is the routine treatment of these fractures in Hastings. The aim of this policy is rapid return of the patient to independence, which is so much more difficult to achieve after a prolonged stay in hospital.

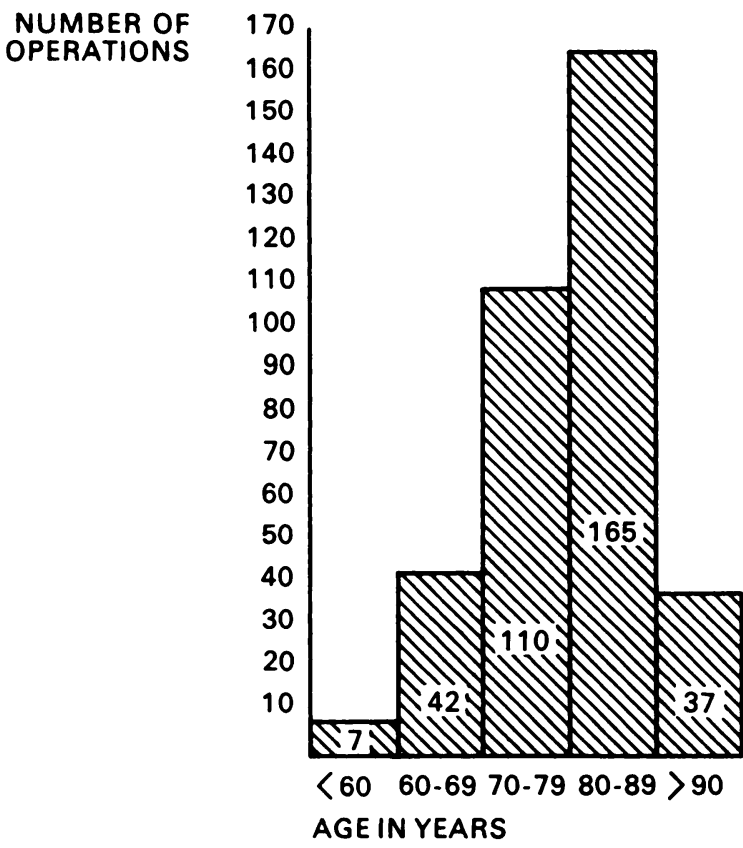

Total number of operations: 361

Average age of patients :

81.3 years

Fig. 1

Age of patients at operation.

TABLE II

Status of Surgeons

\begin{tabular}{|l|c|}
\hline \multicolumn{1}{|c|}{ Surgeon } & $\begin{array}{c}\text { Per cent of } \\
\text { operations }\end{array}$ \\
\hline Consultant . & 23 \\
Clinical assistant $\cdot$ & 23 \\
Registrar . & 43 \\
Senior house officer & 11 \\
\hline
\end{tabular}

The operation is treated as an incident in rehabilitation (Devas 1974), the management of other problems being facilitated thereafter.

On admission each patient is assessed with particular attention to general health and social background, it being remembered that many of these patients fall and sustain fractures near the hip because of already declining health. Table III shows that 239 patients ( 66 per cent) had at least one severe illness or disability recorded in the notes on admission to hospital, and a further thirteen patients ( 3.6 per cent) had other fractures. The operation was done after adequate resuscitation. Most patients in this series were operated upon within thirty hours of the injury. Prophylactic antibiotics were used as a routine.

The operation-Each operation was performed through the antero-lateral approach, between the tensor fasciae latae and the gluteus medius, the fascia lata being split distally. A Thompson prosthesis of suitable size (Table IV) was cemented in position. Usually no attempt was made to repair the capsule and each wound was closed with suction drainage. At least one litre of blood was transfused as a routine. Usually the operation took no longer than forty minutes when done by an experienced surgeon.

TABLE III

Associated Diseases

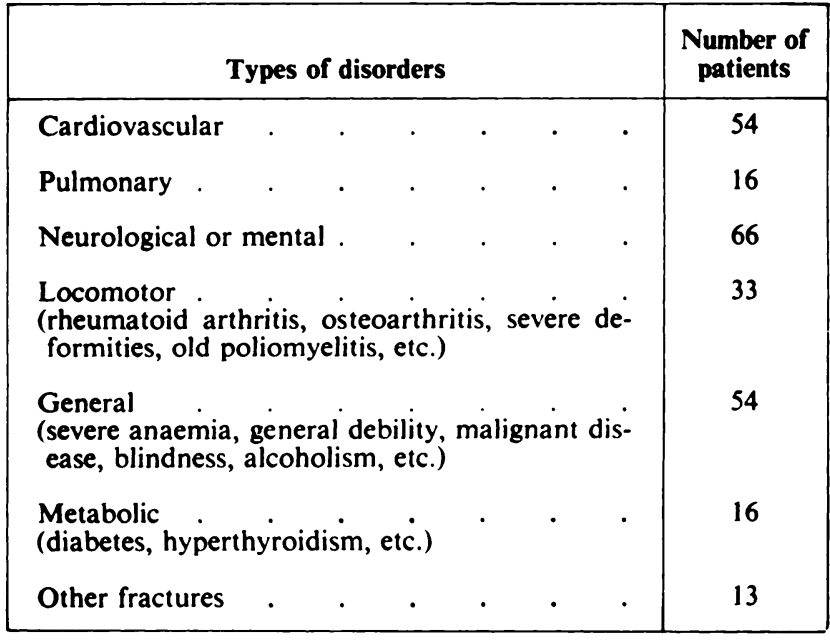

TABLE IV

Size of Prostheses

\begin{tabular}{|c|c|}
\hline $\begin{array}{c}\text { Diameter of head } \\
\text { (inches) }\end{array}$ & Per cent used \\
\hline $1 \frac{1}{2}$ & 2 \\
$1 \frac{5}{8}$ & 12 \\
$1 \frac{3}{7}$ & 50 \\
17 & 27 \\
2 & 5 \\
21 & 4 \\
\hline
\end{tabular}

After-care-From the day after operation each patient was encouraged to walk without restriction of weightbearing. In this way confidence was restored so that most patients made rapid progress from the use of a walking frame with assistance, to independent walking with some other form of walking aid. Early discharge from hospital was allowed whenever the circumstances were suitable. Often the sutures were removed at home by the District Sister. A geriatric orthopaedic unit (Devas and Irvine 1969) was used to rehabilitate patients with severe medical, social or senility problems. 


\section{RESULTS}

The operation was usually well tolerated and 47.4 per cent of patients were discharged from hospital within four weeks of the operation (Table V). Twenty-three patients

TABLE V

Discharge back to Previous Environment

\begin{tabular}{|c|c|c|}
\hline Period after operation & $\begin{array}{c}\text { Number of } \\
\text { hips }\end{array}$ & $\begin{array}{c}\text { Percentage } \\
\text { of hips }\end{array}$ \\
\hline Two weeks & 48 & $13 \cdot 3$ \\
\hline Two to four weeks . & 123 & $34 \cdot 1$ \\
\hline Four to eight weeks. & 54 & $14 \cdot 9$ \\
\hline Eight weeks to six months & 23 & $6 \cdot 4$ \\
\hline Number requiring long-term care & 23 & 6.4 \\
\hline Not known & 26 & $7 \cdot 2$ \\
\hline Died in hospital & 64 & $17 \cdot 7$ \\
\hline Total & $361^{*}$ & $100 \cdot 0$ \\
\hline
\end{tabular}

* 354 patients but seven patients had a second admission for a fracture of the opposite hip.

TABLE VI

Late Results at Review in 161 Hips

\begin{tabular}{|l|l|c|}
\hline Grade & \multicolumn{1}{|c|}{ Criteria } & $\begin{array}{c}\text { Percentage } \\
\text { of reviewed } \\
\text { patients }\end{array}$ \\
\hline Excellent & $\begin{array}{l}\text { Nopain or minimal ache after prolonged } \\
\text { exertion. No additional aids. Endur- } \\
\text { ance and independence unchanged. No } \\
\text { deterioration. Movements normal or } \\
\text { near normal }\end{array}$ & 44 \\
Fair & $\begin{array}{l}\text { As for excellent but endurance a little } \\
\text { reduced. Occasionally one stick re- } \\
\text { quired for distance } \\
\text { Pain of moderate severity occasionally } \\
\text { required analgesics. One or two sticks } \\
\text { required. Endurance considerably re- } \\
\text { duced. Independence reduced. De- } \\
\text { teriorating } \\
\text { Pain moderate to severe. Analgesics } \\
\text { daily. Mobility and independence } \\
\text { markedly reduced. Two sticks or } \\
\text { crutches required }\end{array}$ & 10 \\
\hline
\end{tabular}

(6.4 per cent) did not regain sufficient independence to return to their former homes.

Late results in 161 hips in 156 patients were studied at follow-up. Three patients were too ill from unrelated causes to allow assessment and are not included; nor were twenty-one patients known to be surviving but for whom the documentation was insufficient (Table I).

One hundred and sixty-one hips reviewed were classified into one of four categories. In contrast to the suggestion of Reynolds (1958), pre-existing disability was not allowed to influence the grading. Particular attention was paid to the effect of the fracture on independence, and to deterioration in hip function (that is, reduced mobility or increasing pain) since leaving hospital. The results are shown in Table VI. It will be seen that 82 per cent of the hips reviewed were good or excellent and 18 per cent unsatisfactory. The latter group included all of those still living who had undergone revision operations.

\section{EARLY COMPLICATIONS}

The early complications are shown in Table VII. Confusion, incontinence, urinary tract infections and pressure sores were common temporary problems of the very old and frail

TABLE VII

EARLY COMPLICATIONS

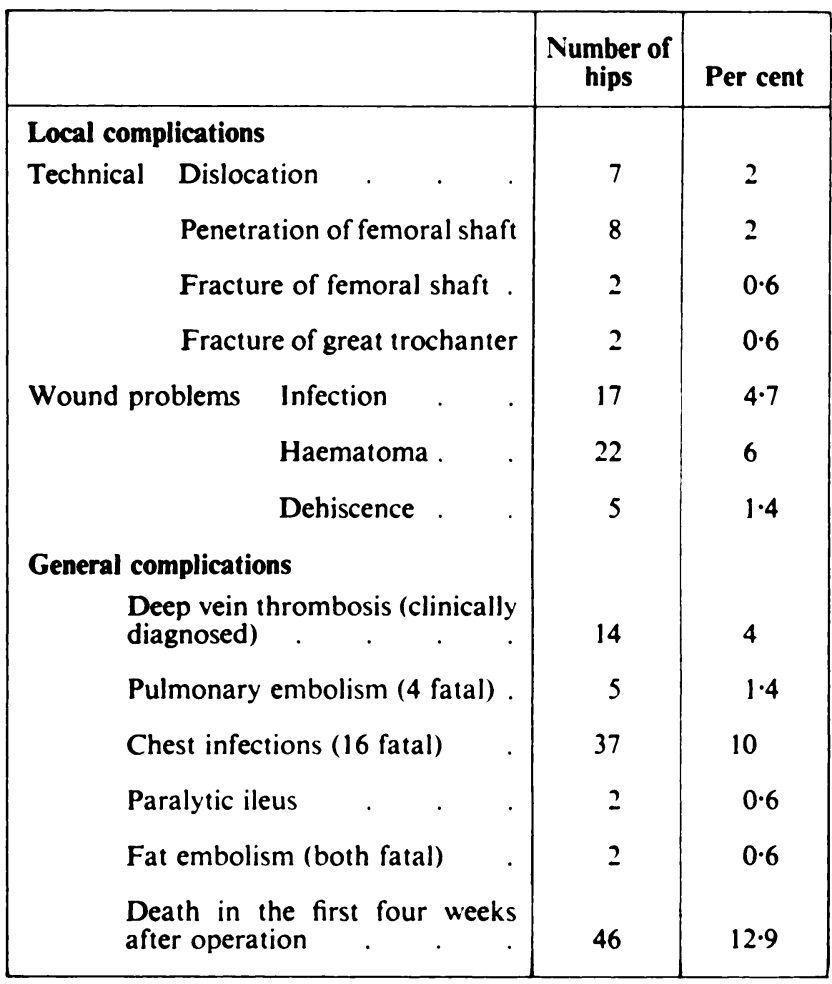

There were seven dislocations in the series ( 2 per cent). Reduction was achieved in six. The cause was usually apparent on reviewing the radiograph taken after operation. In three patients the prosthesis had been inserted in an anteverted position, with penetration of the femoral shaft by the prosthetic stem in two of these. In two patients fracture of the greater trochanter at operation caused instability. The prosthesis was too large in one patient who dislocated the hip in a fall soon after discharge from hospital. In the last patient the prosthesis was correctly positioned but there was a crack fracture in the calcar femoralis. Three of these patients died within three months of operation. One patient had the prosthesis removed for persistent dislocation and survived for twenty-nine months. Another patient had satisfactory 
function after reduction until death eighteen months later. Two patients survived after reduction for final review with satisfactory function.

In eight patients ( 2 per cent) the stem of the prosthesis penetrated the femoral cortex to a significant extent, and in three of these symptoms necessitated removal of the protruding tip with a diamond saw (Figs. 2 and 3 ). persistently high sedimentation rate until his death from unrelated disease fifteen months later.

The clinical incidence of deep vein thrombosis as recorded in the case notes ( 4 per cent) was probably much lower than the true incidence. Five patients had pulmonary emboli, of which four were fatal. Chest infections were the commonest cause of early death (Table VIII).

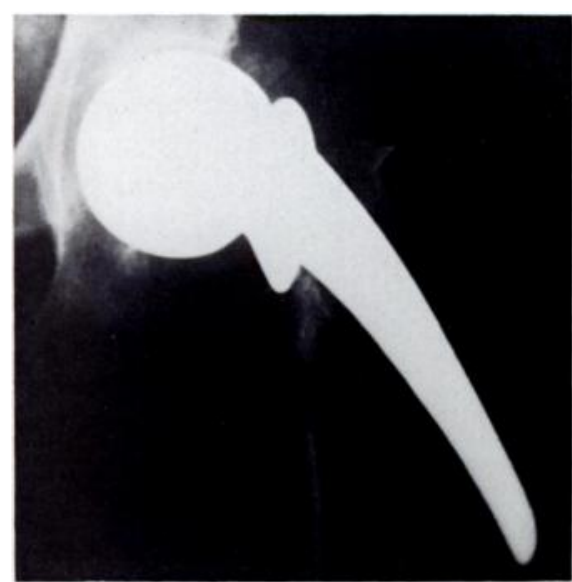

FIG. 2

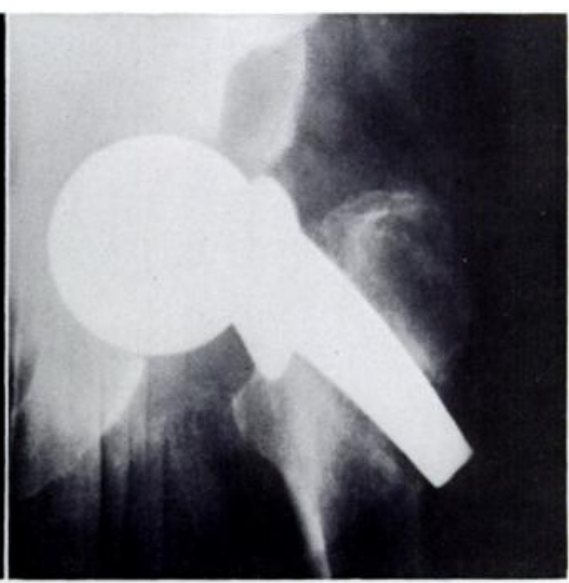

FIG. 3

A very badly done Thompson replacement. The stem has gone through the posterior femoral cortex (Fig. 2). The protruding stem was removed by a diamond saw but later the prosthesis became loose as is shown (Fig. 3 ) by the halo surrounding the stem.

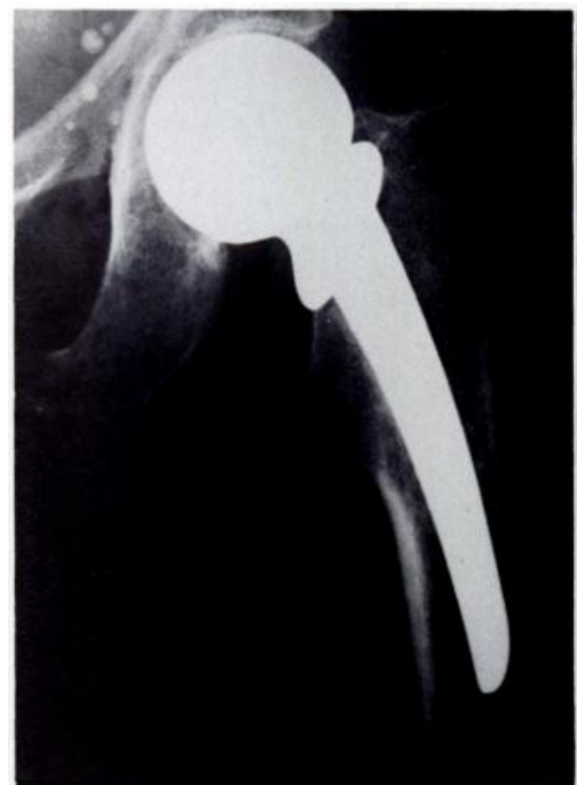

FIG. 4

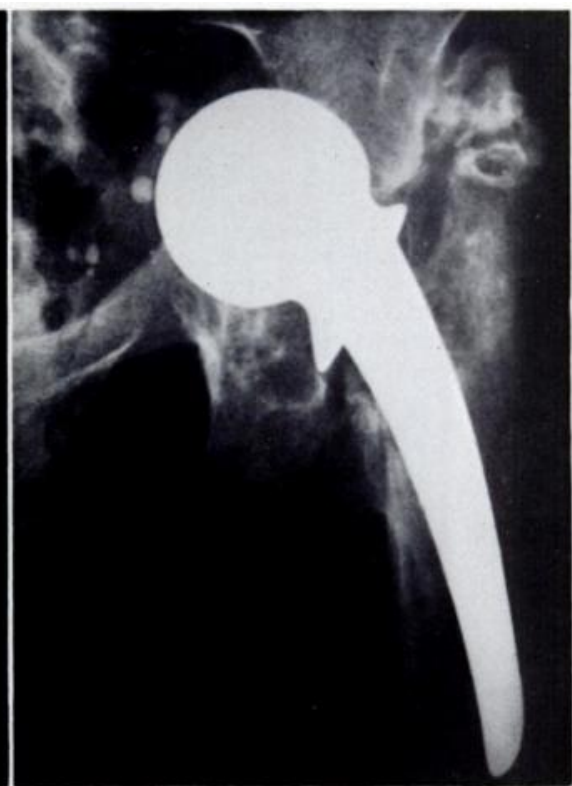

FiG. 5

A patient developed superficial infection after Thompson replacement (Fig. 4) but it was not necessary to remove the prosthesis and Figure 5 shows the ectopic ossification and the advanced protrusion of the prosthesis six months later.

Two fractures of the femoral shaft caused by the operation were treated by replacing the Thompson with a Minneapolis prosthesis. Wound problems included an infection rate of 4.7 per cent but these were mainly superficial and eventually healed in all cases. However, in one patient with early wound infection the prosthesis rapidly eroded the acetabulum (Figs. 4 and 5); he had a
Fat embolism caused two deaths, one of them during operation soon after insertion of the prosthesis. This complication is presumably related to the use of cement to fix the intramedullary prosthesis (Sevitt 1972). Venting of the medullary cavity with suction applied to a catheter down the femoral shaft during insertion of the cement was done routinely*

* Should the catheter fail to suck properly, it usually indicates that the femoral cortex has been broached and a false passage made. This test, noted by Harry Friend, F.R.C.S., a house surgeon at the time, is invaluable and should never be disregarded. 
TABLE VIII

Causes of Death in the First four Weeks after Operation

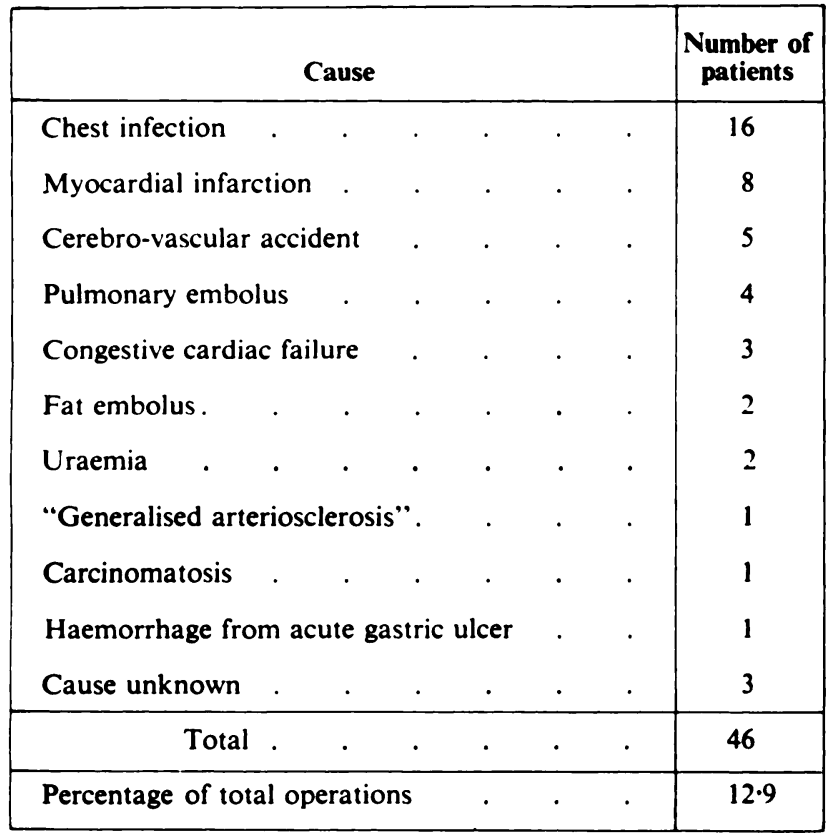

TABLE IX

Causes of late Deterioration in Reviewed Group of 161 Patients

\begin{tabular}{|c|c|c|}
\hline Cause & $\begin{array}{c}\text { Number of } \\
\text { patients }\end{array}$ & $\begin{array}{l}\text { Percentage of } \\
\text { reviewed group }\end{array}$ \\
\hline Acetabular erosion & 18 & 11 \\
\hline Loosening (suspected or confirmed) & 10 & $6 \cdot 1$ \\
\hline Low-grade infection & 3 & $1 \cdot 8$ \\
\hline Total. & 31 & $18 \cdot 9$ \\
\hline
\end{tabular}

TABLE $X$

Mortality in Detall.

\begin{tabular}{|c|c|c|c|c|}
\hline $\begin{array}{c}\text { Time after } \\
\text { operation }\end{array}$ & $\begin{array}{c}\text { New } \\
\text { deaths }\end{array}$ & $\begin{array}{c}\text { Average age } \\
\text { at operation } \\
\text { of new deaths } \\
\text { (years) }\end{array}$ & $\begin{array}{c}\text { Total } \\
\text { number of } \\
\text { patients } \\
\text { dead }\end{array}$ & $\begin{array}{c}\text { Per cent of } \\
\text { patients } \\
\text { dead }\end{array}$ \\
\hline 24 hours & 12 & 85 & 12 & 3 \\
1 week & 12 & 86 & 24 & 6 \\
4 weeks & 22 & 85 & 46 & 12 \\
6 weeks & 8 & 84 & 54 & 15 \\
3 months & 20 & 82 & 74 & 20 \\
6 months & 10 & 86 & 84 & 23 \\
1 year & 15 & 84 & 99 & 27 \\
\hline
\end{tabular}

\section{LATE COMPLICATIONS}

Thirty-one patients admitted to an increase in pain and deterioration in function from the time of leaving hospital (Table IX). Eighteen were found to have various degrees of acetabular erosion (Figs. 7 and 8). The severity of symptoms did not always correspond to the radiographic changes and in some of these patients hip function was still satisfactory. Usually the onset of symptoms occurred in the second or third year after operation. Aching after exertion, loss of endurance and barometric aching were the most common complaints. Occasionally erosion occurred earlier: one patient needed revision by total replacement fourteen months after a Thompson arthroplasty. This complication was more common in younger patients (Fig. 6); their average age was sixty-nine. A review of the radiographs after operation suggested that a long neck stump and a prosthesis slightly too large were unfavourable factors. Addison (1969) recommended that the chosen prosthetic head should be tried for fit in the acetabulum before insertion of its stem in the medullary canal.

In ten patients the suspected cause of deterioration was loosening of the prosthesis within the femur. The

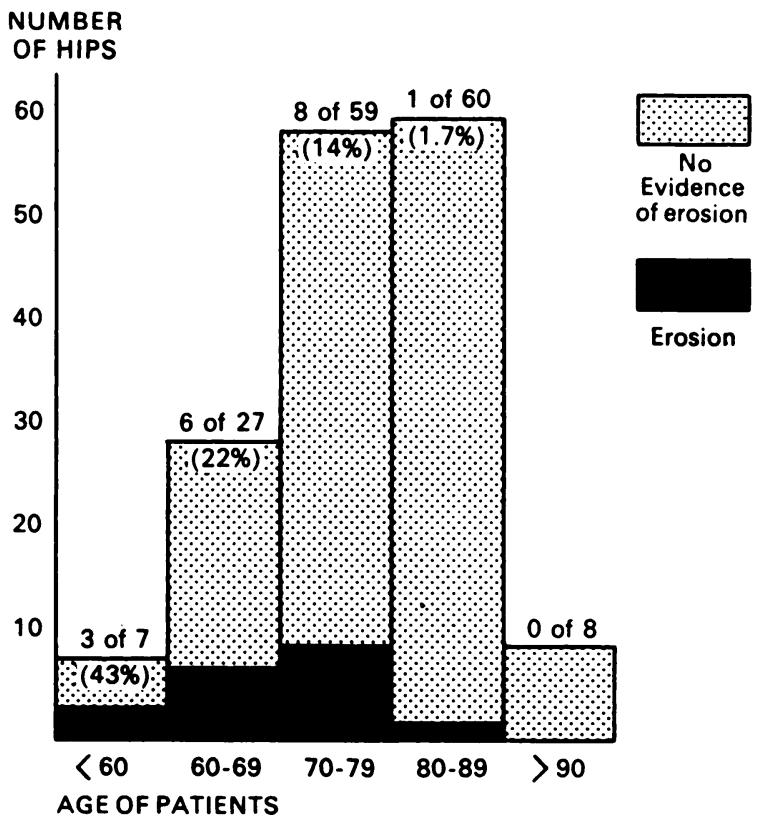

Fig. 6

Incidence of acetabular erosion in 161 reviewed hips related to age of the patient.

onset of symptoms often followed a fall, and characteristically the hip was most painful when walking was started after sitting or lying but improved after a few paces. Presumably walking temporarily seats the prosthesis more firmly within the femur. Pain felt at the extremes of passive rotation was also suggestive of loosening. Radiographic changes were not always present especially when radiolucent cement had been used. When present, a halo surrounding the prosthesis and cement confirmed loosening. 
In three patients low grade infection was the suspected cause of deterioration. One patient, who had had pyrexia early after operation with wound inflammation exertion. The sedimentation rate was raised in all three patients. In a fourth patient a protruding prosthetic stem had been trimmed off soon after the original operation

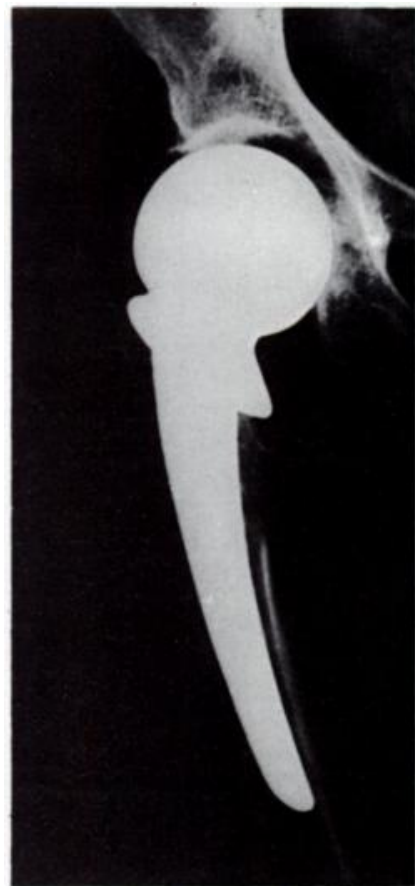

FIG. 7

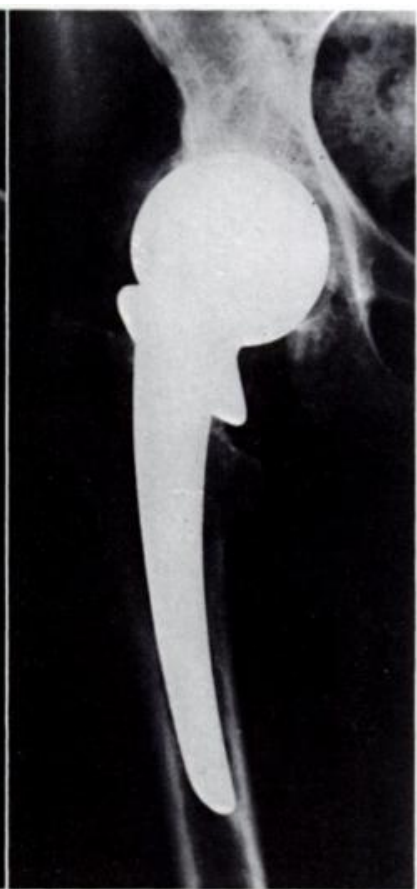

FIG. 8

An example of acetabular erosion. The cemented Thompson prosthesis appears radiologically to be a little too large for the acetabulum and this may be one cause of erosion (Fig. 7). Four years after operation there has been considerable upward erosion with some ectopic ossification (Fig. 8).

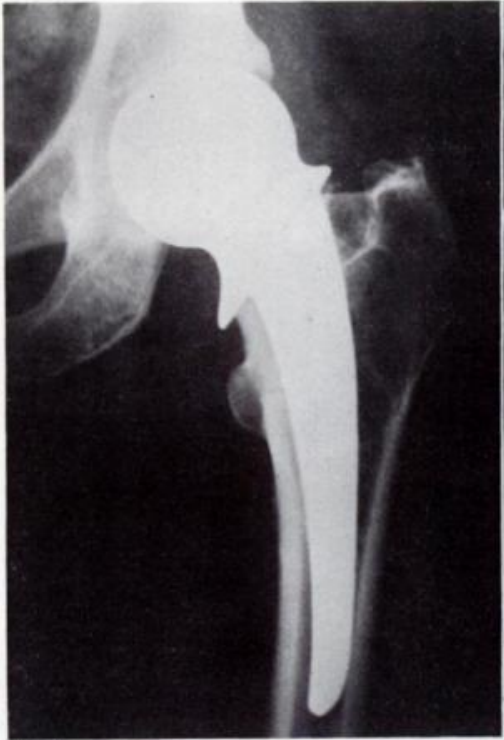

FIG. 9

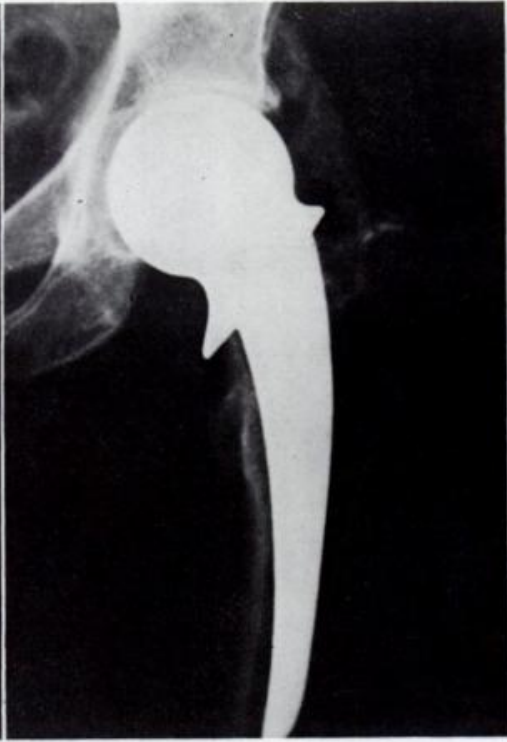

FiG. 10

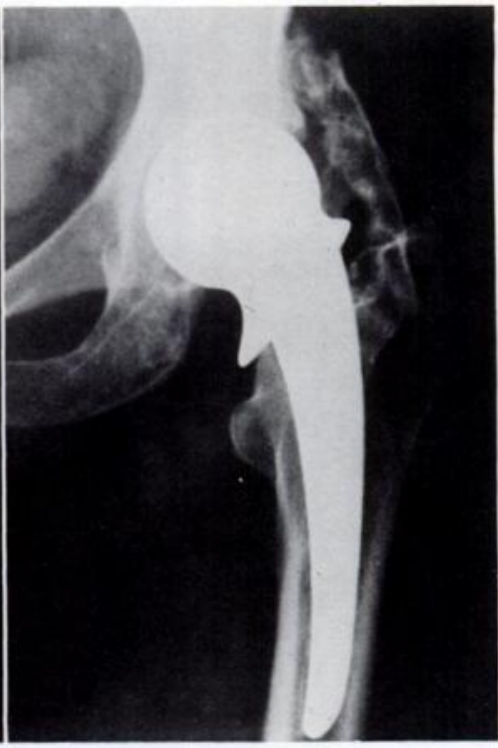

FIG. 11

The development of ectopic ossification. Figure 9 shows a normal appearance after operation but at six weeks (Fig. 10) there was ossification present, and four years later (Fig. I1) it had solidified and organised but without causing great disability.

but no discharge, developed an intermittent sinus from which repeated swab cultures were negative. A similar early infection in two other patients settled, but the endresult was graded as unsatisfactory because of pain after
(Fig. 3). Loosening followed, and when revision was undertaken oedema of the tissues suggested infection and a swab grew staphylococcus albus. She was left with an excision arthroplasty. Extensive new bone formation was 
present in six patients in whom late post-operation radiographs were available (Figs. 9 to 11 ). Their average age was seventy-nine. Stiffness was the only symptom, with usually no more than 25 per cent restriction of the normal non-union or avascular necrosis in the survivors. Also, where figures of the two procedures are compared from one unit there has been selection, and it is the younger patients who have had internal fixation.

TABLE XI

Comparative Mortality Rates

\begin{tabular}{|c|c|c|c|c|c|}
\hline \multicolumn{2}{|c|}{ Author } & $\begin{array}{l}\text { Number of } \\
\text { patients }\end{array}$ & $\begin{array}{c}\text { Average age } \\
\text { of series } \\
\text { (years) }\end{array}$ & $\begin{array}{l}\text { Period after } \\
\text { operation }\end{array}$ & $\begin{array}{c}\text { Mortality } \\
\text { rate } \\
\text { (per cent) }\end{array}$ \\
\hline Addison (1959) & . & 53 & 79 & 6 weeks & 30 \\
\hline Hinchey and D & (1964). & 288 & - & $\begin{array}{l}3 \text { months } \\
6 \text { months }\end{array}$ & $\begin{array}{l}10 \\
14\end{array}$ \\
\hline Burwell (1967) & . & 131 & 74 & $\begin{array}{l}1 \text { month } \\
6 \text { months }\end{array}$ & $\begin{array}{l}14 \\
27\end{array}$ \\
\hline Hunter (1969) & . & 94 & 79 & 1 month & 16 \\
\hline Wrighton and $\mathrm{V}$ & odyard (1971) & 154 & - & $\begin{array}{l}1 \text { month } \\
6 \text { months }\end{array}$ & $\begin{array}{l}16 \\
39\end{array}$ \\
\hline Riska (1970). & . & 122 & - & $\begin{array}{l}1 \text { month } \\
5 \text { months }\end{array}$ & $\begin{array}{l}9 \cdot 8 \\
20^{-1}\end{array}$ \\
\hline Lunt (1971) . & . & 98 & - & $\begin{array}{l}1 \text { month } \\
6 \text { months }\end{array}$ & $\begin{array}{l}22 \cdot 5 \\
31\end{array}$ \\
\hline Raine (1973) & . & 52 & 77 & 6 months & 33 \\
\hline Present series. & . & 361 & 81 & $\begin{array}{l}1 \text { month } \\
6 \text { months }\end{array}$ & $\begin{array}{l}13 \\
23\end{array}$ \\
\hline
\end{tabular}

range of movement. New bone formation is probably a common phenomenon, especially in older patients.

At the time of writing six patients have undergone revision by total replacement-four for acetabular erosion and two for loosening. A further four patients are awaiting this operation.

\section{MORTALITY}

A high early mortality is inevitable after operations to rehabilitate these elderly patients (Table X). Age is the single most important factor influencing prognosis (Reno and Burlington 1958) (Fig. 12). In comparing the relative mortality in different series, as for different methods of treatment, it is essential to know the average overall age. The state of health before operation is also of great importance, though not easy to compute in comparing the effect of different methods of treatment. The comparative mortality rates for those series reporting the results of treatment of hip fractures by arthroplasty is given in Table XI.

In 1964 Smyth, Ellis, Manifold and Dewey had a mortality of 18.3 per cent one month after internal fixation of fractured necks of femur in seventy-one patients with an average age of eighty years. Other than this no useful figures have been found in the literature for direct comparison between the survival after simple nailing procedures and replacements; probably this is because in the former, emphasis is laid on the failure rate from

\section{DISCUSSION}

Although the radical policy of primary replacement arthroplasty for femoral neck fractures is still controversial, it is justified in that it is no more dangerous for the patient than internal fixation (Reynolds 1958) and permits

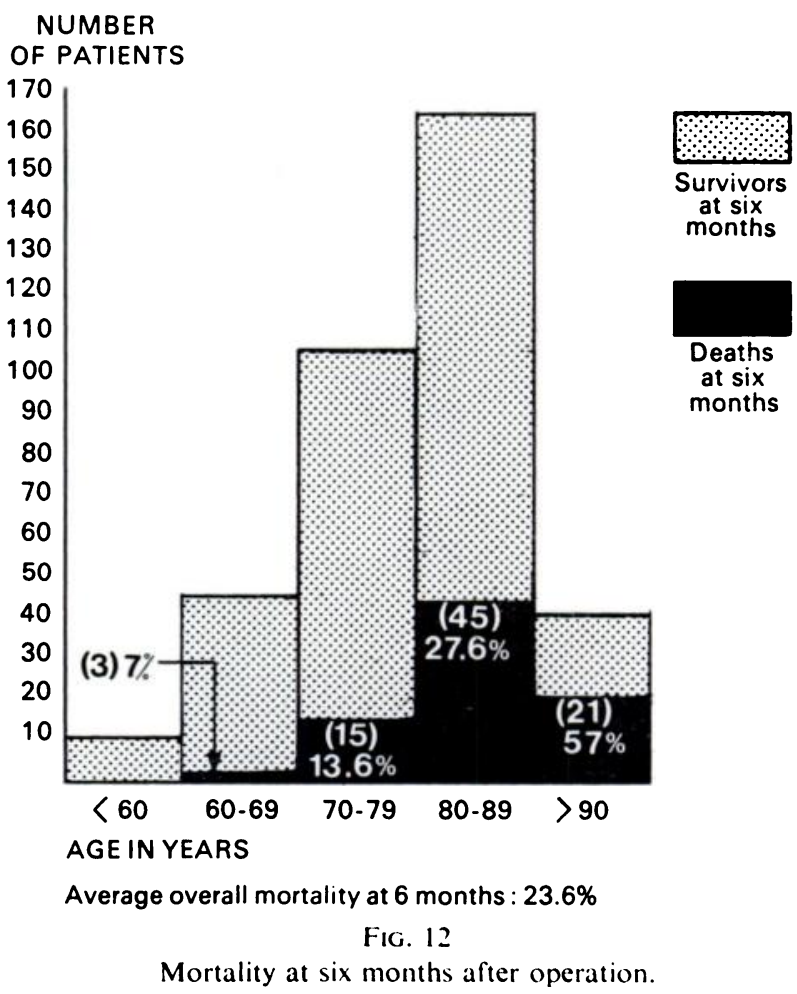


more rapid mobilisation and return to independence. The antero-lateral approach is preferred because it allows full unrestricted mobilisation, including sitting, without fear of dislocation. A correctly inserted prosthesis seldom dislocates.

The immediate stability afforded by cementing the prosthesis results in freedom from pain and a sense of security in the early days after operation, thus allowing the patient to achieve early mobility with consequent improvement in morale. It must be accepted that the presence of old cement increases the difficulty of operation in those few patients who require surgical revision by total hip replacement.

The high rate of general complications and the high early mortality usually expected in old and ill patients can both be kept down by early definitive surgery, excellent nursing and geriatric management based on a team approach to rehabilitation which is best achieved within a geriatric orthopaedic unit.

Acetabular erosion and loosening are shown to be the important late complications. The tendency for acetabular erosion to occur mainly in younger patients is probably related to their better survival and greater demands; new developments in prostheses may reduce this complication. Meanwhile it seems prudent to withhold primary Thompson arthroplasty from younger patients except when other infirmities make prolonged survival unlikely.

\section{REFERENCES}

Addison, J. R. (1959) Prosthetic replacement in the primary treatment of fracture of the femoral neck. Proceedings of the Royal Society of Medicine, 52, 908-910.

Addison, J. R. (1969) In Operative Surgery. Edited by C. Rob and R. Smith. Volume 8. Orthopaedics, p. 249. Edited by R. Furlong. London: Butterworth and Company Ltd.

Barnes, R. (1970) Problems in the treatment of femoral neck fractures. Proceedings of the Royal Society of Medicine, 63, $1119-1120$.

British Medical Journal (1969) Pin or prosthesis. British Medical Journal, 2, 201.

Boyd, H. B., and Salvatore, J. E. (1964) Acute fracture of the femoral neck; internal fixation or prosthesis? Journal of Bone and Joint Surgery; 46-A, 1066-1068.

Burwell, H. N. (1967) Replacement of the femoral head by a prosthesis in subcapital fractures. British Journal of Surgery, 54, 741-749.

Cooper, Sir A. P. (1822) Treatise on Dislocations and on Fractures of the Joints. London: Longman, Hurst, Rees, Orme and Brown; and E. Cox and Son.

Devas, M. B. (1974) Geriatric orthopaedics. British Medical Journal, 1, 190-192.

Devas, M. B., and Irvine, R. (1969) The geriatric orthopaedic unit-A method of achieving return to independence in the elderly patient. British Journal of Geriatric Practice, 6, 19-24.

Dickson, J. A. (1953) The unsolved fracture. Journal of Bone and Joint Surgery, 35-A, 805-822.

Garden, R. S. (1961) Low-angle fixation in fractures of the femoral neck. Journal of Bone and Joint Surgery, 43-B, 647-663.

Garden, R. S. (1964) Stability and union in subcapital fractures of the femur. Journal of Bone and Joint Surgery, 46-B, 630-647.

Hinchey, J. J., and Day, P. L. (1964) Primary prosthetic replacement in fresh femoral neck fractures. Journal of Bone and Joint Surgery, 46-A, 223-240.

Hunter, G. A. (1969) A comparison of the use of internal fixation and prosthetic replacement for fresh fractures of the neck of the femur. British Journal of Surgery, 56, 229-232.

Lunt, H. R. W. (1971) The role of prosthetic replacement of the head of the femur as primary treatment for subcapital fractures. Injury, 3, 107-113.

Moore, A. T. (1952) Metal hip joint-a new self-locking Vitallium prosthesis. Southern Medical Journal, 45, 1015-1018.

Nicoll, E. A. (1963) The unsolved fracture. Journal of Bone and Joint Surgery, 45-B, 239-241.

Raine, G. E. T. (1973) A comparison of internal fixation and prosthetic replacement for recent displaced subcapital fractures of the neck of femur. Injury, 5, 25-30.

Reno, J. H., and Burlington, H. (1958) Fractures of the hip-mortality survey. American Journal of Surgery, 95, 581-589.

Reynolds, F. C. (1958) Preliminary report of the Committee on Fractures and Traumatic Surgery on the use of a prosthesis in the treatment of fresh fractures of the neck of the femur. Journal of Bone and Joint Surgery, 40-A, 877-885.

Riska, E. B. (1970) Factors influencing the primary mortality in the treatment of hip fractures. Injury, 2, 107-115.

Riska, E. B. (1971) Prosthetic replacement in the treatment of subcapital fractures of the femur. Acta orthopaedica Scandinavica, 42, $281-290$.

Sevitt, S. (1972) Fat embolism in patients with fractured hips. British Medical Journal, 2, 257-262.

Smith-Petersen, M. N., Cave, E. F., and Vangorder, G. W. (1931) Intracapsular fractures of the neck of the femur. Treatment by internal fixation. Archives of Surgery, 23, 715-759.

Smyth, E. H. J., Ellis, J. S., Manifold, M. C., and Dewey, P. R. (1964) Triangle pinning for fracture of the femoral neck-a new method based upon the internal architecture. Journal of Bone and Joint Surgery, 46-B, 664-673.

Thompson, F. R. (1954) Two and a half years experience with a Vitallium intramedullary hip prosthesis. Journal of Bone and Joint Surgery, 36-A, 489-500.

Wrighton, J. D., and Woodyard, J. E. (1971) Prosthetic replacement for subcapital fractures of the femur: A comparative survey. Injury, 2, 287-293. 